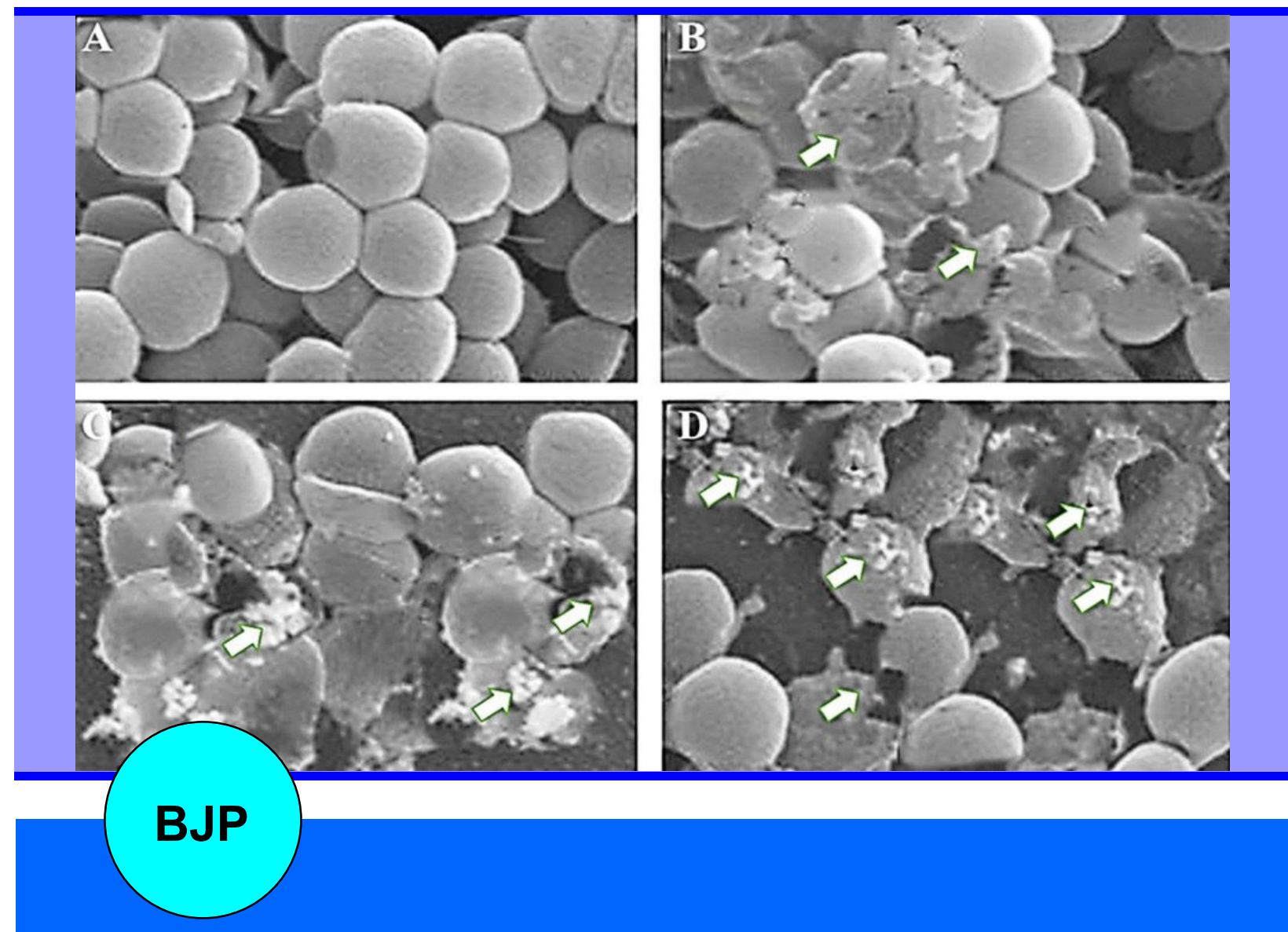

Bangladesh Journal of Pharmacology

Research Article

Antibacterial activity of seneciolactone isolated from Senecio scandens against some common gastrointestinal tract disease causing bacterial pathogens 
Abstracted/indexed in Academic Search Complete, Asia Journals Online, Bangladesh Journals Online, Biological Abstracts, BIOSIS Previews, CAB Abstracts, Current Abstracts, Directory of Open Access Journals, EMBASE/Excerpta Medica, Google Scholar, HINARI (WHO), International Pharmaceutical Abstracts, Open J-gate, Science Citation Index Expanded, SCOPUS and Social Sciences Citation Index;

ISSN: $1991-0088$

\title{
Antibacterial activity of seneciolactone isolated from Senecio scandens against some common gastrointestinal tract disease causing bacterial pathogens
}

\author{
Yi Zheng', Yu Wang' and Yuan-Hong Shang1 \\ ${ }^{1}$ School of Biological and Chemical Engineering, Panzhihua University, Panzhihua City, Sichuan 617 000, P. R. \\ China; ${ }^{2}$ School of Medicine, Panzhihua University, Panzhihua City, Sichuan 617 000, P. R. China.
}

\begin{tabular}{|c|c|}
\hline \multicolumn{2}{|l|}{ Article Info } \\
\hline $\begin{array}{l}\text { Received: } \\
\text { Accepted: } \\
\text { Available Online: }\end{array}$ & $\begin{array}{r}28 \text { August } 2015 \\
3 \text { October } 2015 \\
21 \text { January } 2016\end{array}$ \\
\hline \multicolumn{2}{|c|}{ DOI: 10.3329/bjp.v11i1.24792 } \\
\hline \multicolumn{2}{|c|}{$\begin{array}{l}\text { Cite this article: } \\
\text { Zheng Y, Wang Y, Shang YH. Anti- } \\
\text { bacterial activity of seneciolactone iso- } \\
\text { lated from Senecio scandens agains } \\
\text { some common gastrointestinal tract } \\
\text { disease causing bacterial pathogens } \\
\text { Bangladesh J Pharmacol. 2016; 11: } 218 \\
-23 \text {. }\end{array}$} \\
\hline
\end{tabular}

\begin{abstract}
The objective of the present investigation was to study the antibacterial effect of seneciolactone isolated from the methanolic extract of Senecio scandens against five bacterial pathogens which are known to cause several gastrointestinal tract diseases. Disc diffusion assay and agar well diffusion assays were used to examine the antibacterial efficacy of this compound by measuring zones of inhibition and $\mathrm{MIC} / \mathrm{MBC}$ values. Scanning electron microscopy (SEM) was involved to study the effect of this compound on cellular morphology of Shigella dysenteriae. Results revealed that seneciolactone exhibited moderate to potent antibacterial activity against different bacterial strains. Zones of inhibition and MIC/MBC values indicated that seneciolactone was most potent against S. dysenteriae followed by Pseudomonas aeruginosa and E. coli. SEM results indicated that seneciolactone induced potent damage to the cell membrane of the tested bacteria. As compared to the untreated control which exhibited normal cellular morphology, the seneciolactone treated bacterial cells revealed severe damage to the cellular membrane particularly at the higher doses.
\end{abstract}

\section{Introduction}

The main cause of mortality in tropical and subtropical countries is the bacterial and fungal infections. The pathogenic microbes have developed multidrug resistance due to the excess use of various antibiotics including those of synthetic origin. This has led to the serious health problems especially in developing countries where these microbial infections are quite common. On many occasions, this drug resistance can result in epidemic as no drug can affect this lifethreatening pathogen (Harrison and Svec, 1998; Rao, 1998). The pursuit for antimicrobial compounds has gained increasing significance in recent years, due to growing global concern about the startling increase in the rate of infection by antibiotic resistant microorganisms (Weisser et al., 1996). Nevertheless, there has also been a growing interest in the research for natural products from plants for the discovery of new antimicrobial drugs in the last 30-40 years (Satish et al., 1999; Balandrin et al., 1985). Plants are known to biosynthesize a wide-spectrum of bioactive secondary metabolites such as phenolic compounds, terpenoids, quinones, alkaloids, flavonoids etc with potent antimicrobial activities which certainly has shaped the basis for their applications in some pharmaceuticals, alternative medicines and natural therapies (Satish et al., 1999; Jones, 1996; Brito et al., 2015; Mota et al., 2015).

Many bacterial strains have been reported to cause serious gastrointestinal disorders including irritable bowel syndrome (IBS). IBS is a very common gastrointestinal disorder which involves changes in the gastrointestinal microbial population. Although IBS can 
be treated with several antibiotics, but recently there has been an upsurge in the appearance of antibiotic resistant bacterial strains which are not susceptible to these commonly used antibiotics (Balandrin et al., 1985).

As such, there is an urgent need of alternative antibacterial agents which can target these drug resistant pathogenic microbes. Several plant based medicines have been reported to be effective against these gastrointestinal tract disease causing pathogenic microbes.

The objective of the present study was to investigate the antibacterial activity of seneciolactone isolated from the methanol extract of Senecio scandens against several gastrointestinal tract disease causing bacteria including Escherichia coli, Salmonella typhimurium, S. typhi, Shigella dysenteriae. Pseudomonas aeruginosa. We also investigated effects of this compound on bacterial cell morphology in $S$. dysenteriae using scanning electron microscopy.

\section{Materials and Methods}

\section{Plant material, extraction and isolation}

The aerial plant material of $S$. scandens was collected from Conghua, Guangdong Province (China) in August, 2014. The plant was identified and authenticated by a well-known taxonomist, Prof. Hua-Juan, School of Chinese Medicine, Hong Kong Baptist University. The voucher specimen (HKBU-B-2014-06-39 -042) was deposited at School of Chinese Medicine, Hong Kong Baptist University. The air dried, finely powdered aerial parts $(4 \mathrm{Kg})$ were extracted for 48 hours with chloroform in a soxhlet apparatus to afford the extract, which was concentrated under reduced pressure. The chloroform extract $(70 \mathrm{~g})$ was loaded on silica gel (60-120 mesh, $200 \mathrm{~g}$ ) column and eluted with an increasing gradient of petroleum ether and ethyl acetate. Fractions of $100 \mathrm{~mL}$ volume each were collected and pooled according to TLC analysis. The fraction (petroleum ether: ethyl acetate, 50:50) yielded seneciolactone as yellow colored crystalline solid, M.P. 80-82.5 ${ }^{\circ} \mathrm{C}$; UV $\lambda \max$ (methanol): $197 \mathrm{~nm}, 362 \mathrm{~nm}$; IR: $3420 \mathrm{~cm}^{-1}, 1767 \mathrm{~cm}^{-1}, 1718 \mathrm{~cm}^{-1}, 1610 \mathrm{~cm}^{-1}, 1629 \mathrm{~cm}^{-1}$, $1470 \mathrm{~cm}^{-1}$. The molecular formula of seneciolactone was assigned as $\mathrm{C}_{16} \mathrm{H}_{12} \mathrm{O}_{6}$, from HR-EI-MS spectrometry (m/z 300.0637, calcd 300.0634). The absorptions at 1767 $\mathrm{cm}^{-1}$ in the IR spectrum indicated the presence of a lactone structure. In the ${ }^{13} \mathrm{C}$ NMR spectrum, 16 carbon signals were observed as one methyl, one methylene, six methines and eight quaternaries. From ${ }^{1} \mathrm{H}$ NMR spectrum, we observed a typical ABX coupling system for a 1, 2, 4-trisubstituted aromatic ring $[\mathrm{d} 7.08(1 \mathrm{H}, \mathrm{d})$, $6.85(1 \mathrm{H}, \mathrm{dd}), 7.84(1 \mathrm{H}, \mathrm{d})]$, an a, a-disubstituted furan ring substituted at positions of $[7.35(1 \mathrm{H}, \mathrm{d}), 6.85(1 \mathrm{H}$, d)] and a methyl group $[\mathrm{d} 2.25(3 \mathrm{H}, \mathrm{s})]$, respectively.

\section{Bacterial strains and culture media}

E. coli, S. typhimurium, S. typhi, S. dysenteriae. P. aeruginosa were used in the present study. All these bacterial strains were obtained from the State Key Laboratory of Microbial Resources, Institute of Microbiology, Chinese Academy of Sciences, Shanghai, China. Bacterial strains were grown on nutrient agar plates at $37^{\circ} \mathrm{C}$ and maintained on nutrient agar slants. The cell suspension of microorganisms in $0.5 \% \mathrm{NaCl}$ was adjusted to a 0.5 McFarland standard to obtain $\sim 10^{5}$ colony forming units (CFUs)/mL.

\section{Determination of antibacterial activity by agar well diffusion assay}

Agar well diffusion assay was performed to evaluate the antibacterial effect of seneciolactone. Briefly, the overnight bacterial cell cultures were added to $50 \mathrm{~mL}$ liquid nutrient agar (Sigma-Aldrich). After $30 \mathrm{~min}$ of solidification of the agar, different doses of the compound were added to separate wells on the plates and then incubated for 24 hours at $25^{\circ} \mathrm{C}$. Subsequent to incubation, the antibacterial activity of the compound was evaluated by calculating the zone of inhibition expressed in millimeter. All experiments were done in triplicate. Vancomycin and streptomycin $(20 \mu \mathrm{g} /$ well each; Sigma-Aldrich) served as positive controls.

\section{Evaluation of minimum inhibitory concentration (MIC) and minimum bactericidal concentration (MBC)}

The MIC and MBC screening were performed using the broth microdilution method (Yu et al., 2004) as already reported. Seneciolactone was dissolved in physiological saline solution supplemented with Tween-80 at final concentration of $1.3 \%$. Different concentrations of the compound were prepared in a 96-well microtiter plate. Each compound concentration was put into the wells containing $100 \mu \mathrm{L}$ bacterial suspension and then inoculated. The final concentration of each bacterial strain was adjusted to $10^{5}-10^{6} \mathrm{CFU} / \mathrm{mL}$. The concentration of the compound at which the bacterial pathogens do not exhibit visible growth is described as MIC and the compound concentration at which the bacterial pathogens are killed is defined as MBC. Vancomycin and streptomycin (20 $\mathrm{\mu g} /$ well each; Sigma-Aldrich) served as positive controls.

\section{Scanning electron microscopy (SEM) evaluation}

Scanning electron microscopy was performed as described previously (Agizzio et al., 2006) with minor modification. In brief, $S$. dysenteriae was grown in LB broth to an exponential phase and centrifuged at 12,000 $\mathrm{rpm}$ for $10 \mathrm{~min}$. The compound $(0,10,25$ and $50 \mu \mathrm{M}$, seneciolactone dissolved in DMSO) was mixed with an aliquot of bacterial solution $\left(1 \times 10^{6} \mathrm{CFU} / \mathrm{mL}\right)$ having 5 $\mathrm{mM}$ phosphate buffer, $\mathrm{pH}$ 6.8. Then the bacterial culture was incubated at $37^{\circ} \mathrm{C}$ for 4 hours, followed by 
washing and resuspending in $5 \mathrm{mM}$ phosphate buffer and fixed overnight at $4^{\circ} \mathrm{C}$ with $1.5 \%$ gluteraldehyde. After this, the bacterial cells were washed three times with phosphate buffer and then treated with $0.8 \%$ osmium tetraoxide and then again washed with phosphate buffer followed by washing with distilled water. Subsequently, the bacterial cells were dehydrated with $50 \%$ acetone followed by $100 \%$ and mounted on cover slips to dry and then coated with gold using a sputter coater. Then the bacterial cells were examined using a scanning electron microscope (JEOL JSM 6060 $\mathrm{LV}$, with the accelerating voltage of $5 \mathrm{kV}$ ). Microphotographs were taken at magnifications ranging from $100 x$ to $5000 x$.

\section{Statistical analysis}

All experiments were performed in triplicate and the results are expressed as the mean \pm standard deviation. Graphpad Prism version 5.01 (Graphpad Software, Inc., La Jolla, CA, USA) was used to perform statistical analyses and $\mathrm{p}<0.05$ was considered to indicate a statistically significant difference.

\section{Results}

\section{Antibacterial activity against various bacterial strains}

The molecular structure of seneciolactone is shown in Figure 1. The antibacterial efficacy of seneciolactone isolated from $S$. scandens was evaluated against five gastrointestinal tract infection causing bacteria including E. coli, S. typhimurium, S. typhi, S. dysenteriae and $P$. aeruginosa. The antibacterial activity was expressed by measuring the zone of inhibition and MIC/MBC values against different bacteria. Figures 2 and 3 show the results of disc diffusion assay expressed as zones of inhibition while as Table I shows the MIC/ MBC values of the compound against these tested bacteria. Seneciolactone exhibited a broad spectrum antibacterial effect against these five tested bacterial strains. E. coli, S. typhimurium and S. typhi were the lesser susceptible bacterial strains. S. dysenteriae at all the tested doses was the most susceptible bacterial strain with zone of inhibition almost equal to that of

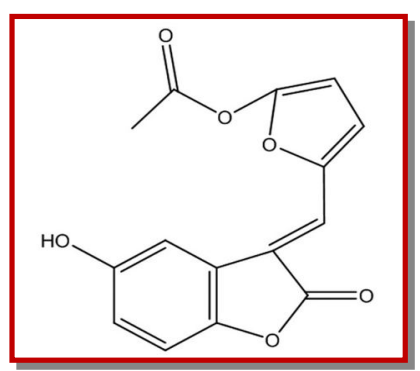

Figure 1: Chemical structure of seneciolactone isolated from Senecio scandens vancomycin. Vancomycin at a dose of $2.0 \mu \mathrm{M}$ was used as a positive control.

Table I shows the MIC/MBC values of seneciolactone against these five tested bacteria at different doses. From the table also, it appeared that $S$. dysenteriae exhibited the lowest values of both MIC as well as MBC indicating that seneciolactone was most effective against this bacterial strain.

\section{Morphological evaluation of the effect of senecio- lactone on S. dysenteriae using SEM}

Since $S$. dysenteriae was the most susceptible bacterial strain, we further examined the effect of seneciolactone on the cell morphology of this bacterial pathogen using scanning electron microscopy. SEM findings revealed that seneciolactone damages the cell membrane of $S$. dysenteriae. As compared to the untreated control which exhibited normal cellular morphology, the seneciolactone treated bacterial cultures (Figure 4) showed serious damage to the cellular membrane particularly at the higher doses. As the concentration of seneciolactone increased, the membrane damage also increased.

\section{Discussion}

In the present study, the antibacterial effect of seneciolactone isolated from the methanol extract of $S$. scandens was observed against a panel of clinically relevant gastrointestinal tract infection causing bacterial pathogens including E. coli, S. typhimurium, S. typhi, S. dysenteriae and $P$. aeruginosa. The results revealed that seneciolactone displayed a broad spectrum antibacterial activity with maximum effect on $S$. dysenteriae showing maximum zone of inhibition and lowest MIC/MBC values. Further, scanning electron microscopic examination revealed that seneciolactone induced cellular membrane damage in S. dysenteriae. As compared to the untreated pathogens which revealed normal cell morphology with no obvious damage, seneciolactonetreated bacterial cultures revealed lethal destruction of the cell membrane.

S. scandens locally known as "Qianliguang" in China, is one of the most popular species used as a Chinese medicinal herb. Various natural product compounds including pyrrolizidine alkaloids, alkaloids, phenolic acids, flavonoids, terpenes, essential oils, carotenoids and jacaranone glycosides have already been isolated from S. scandens (Bohlmann et al., 1977; Batra and Rajagopalan, 1977; Wang and Tu, 1980; Tian et al., 2006). Although seneciolactone has already been reported from this plant, but till date there are no reports on the antibacterial effect of seneciolactone against these gastrointestinal tract disease causing microbes. However, extracts of $S$. scandens have been shown to possess a wide range of pharmacological activities 


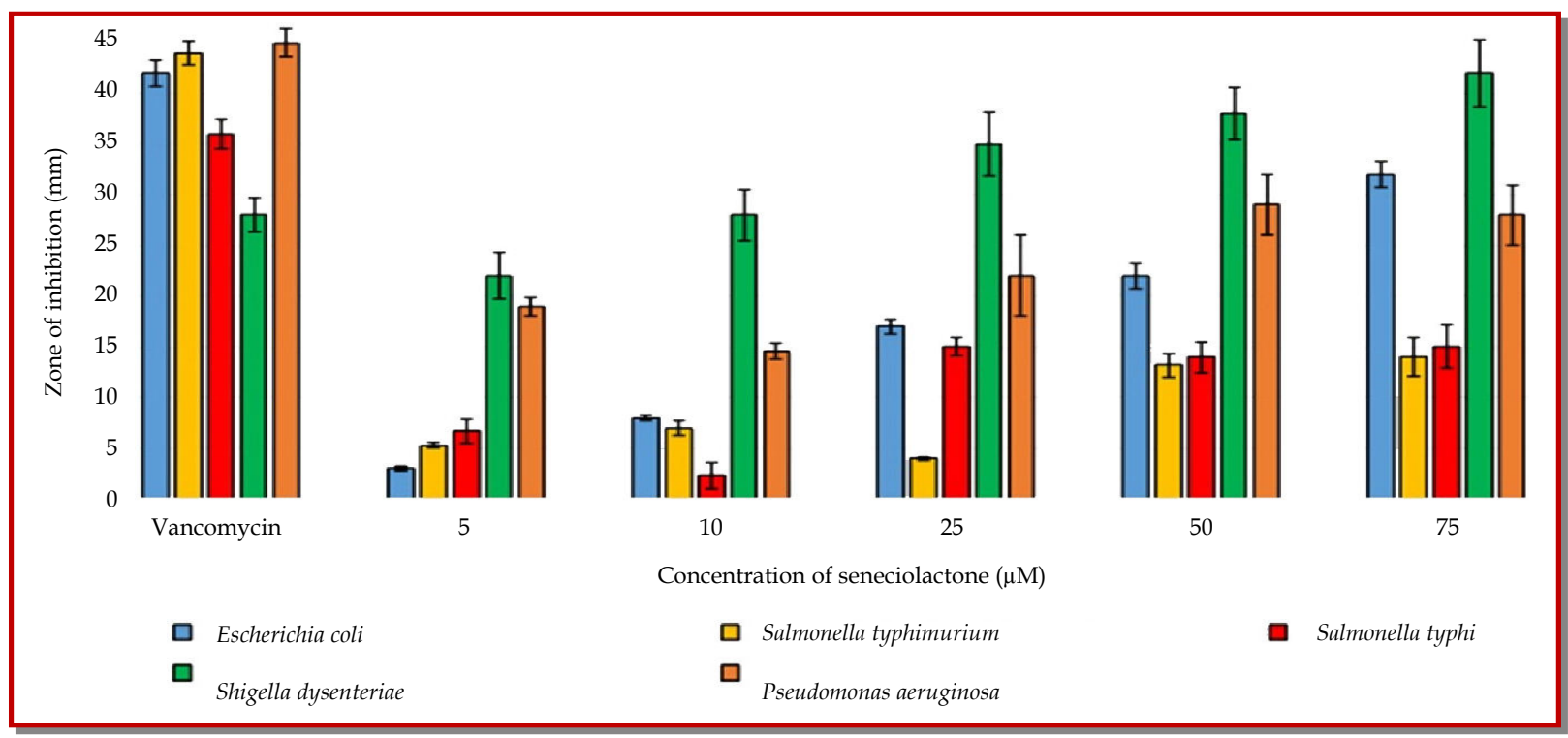

Figure 2: Seneciolactone shows a wide-range of antibacterial effect against the five tested bacterial strains. Effect of different concentrations of seneciolactone on the zones of inhibition (antibacterial effect) of the several tested bacterial strains. Shigella dysenteriae was the most susceptible pathogenic bacteria at all tested doses

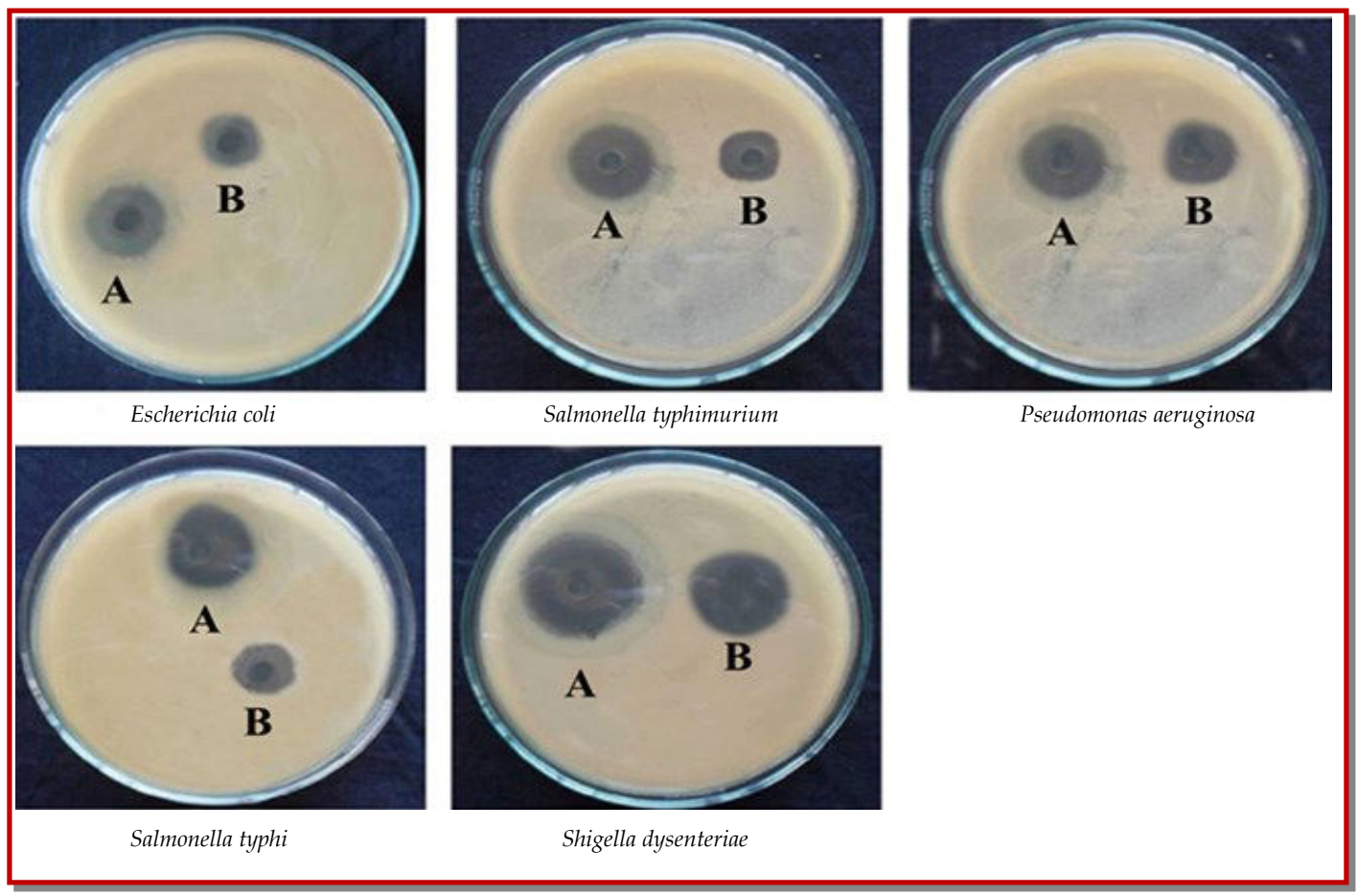

Figure 3: The evaluation of antibacterial effect of seneciolactone against five bacterial strains using disk diffusion assay. A and B represent zone of inhibition due to vancomycin and seneciolactone respectively

including anti-inflammatory, antimicrobial, hepatoprotective, antioxidant, antiviral, antitumor, mutagenic and toxicological activities (Wang et al., 2013).

It is important to mention here that most of the antiinfectious drugs happen to be derived from natural sources including plants and microbes. Many of these secondary metabolites also function as models for the production of effective and novel antibiotics. The hydrophobic nature of plant based natural products is their hydrophobic nature which makes them able to partition the lipid bilayer of the cell membrane and therefore cause damage of the cell membrane and render them permeable to the compound effects. Many plant derived compounds including phenols, quinones, terpenoids, flavones have been reported to possess antibacterial activity. (Djouossi et al., 2015; Cabral et al., 2015). 
Table I

MIC and MBC values of seneciolactone and the standard antibacterial drug (vancomycin) against a panel of five bacterial strains

\begin{tabular}{|lcccc|}
\hline Microbes & \multicolumn{2}{c|}{ Seneciolactone $(\mu \mathrm{M})$} & \multicolumn{2}{c|}{ Vancomycin $(\mu \mathrm{M})$} \\
\cline { 2 - 5 } & MIC & MBC & MIC & MBC \\
Escherichia coli & 47.2 & 72 & 0.3 & 0.9 \\
Salmonella typhimurium & 44.3 & 67 & 0.3 & 0.9 \\
Salmonella typhi & 49.6 & 74.4 & 0.5 & 0.9 \\
Shigella dysenteriae & 26.7 & 50.3 & 0.7 & 1.0 \\
Pseudomonas aeruginosa & 46.3 & 74.2 & 0.4 & 0.9 \\
\hline
\end{tabular}

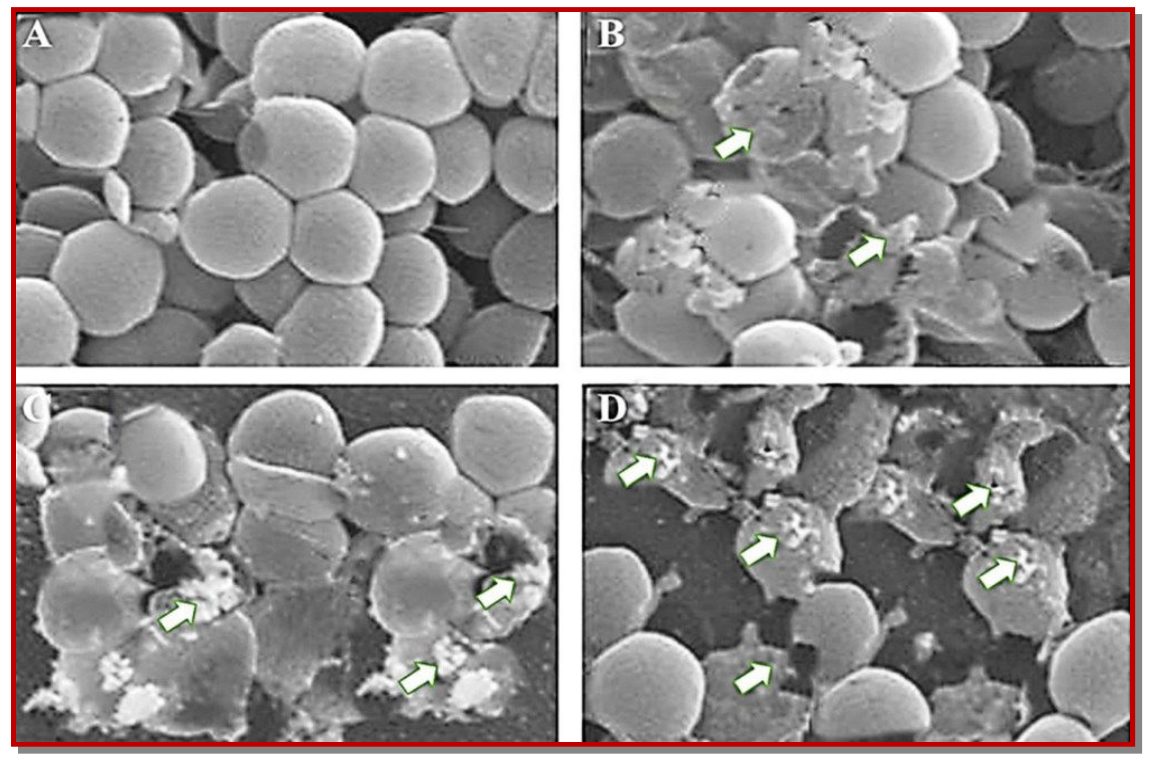

Figure 4: Effect of different doses of seneciolactone on the cell membrane integrity of Shigella dysenteriae using scanning electron microscopy. As compared to the untreated control (A), $10 \mu \mathrm{M}$ (B), $25 \mu \mathrm{M}$ (C) and $50 \mu \mathrm{M}$ seneciolactone-treated bacterial cultures revealed significant damage to the cellular membrane (white arrows)

\section{Conclusion}

Seneciolactone shows antibacterial activity against five common bacteria which are known to cause several gastrointestinal tract disorders including IBS. The molecule showed medium to potent antibacterial activity against different bacteria. Further, the antibacterial effect of this compound was mediated through the destruction of cell membrane in $S$. dysenteriae.

\section{Conflict of Interest}

The authors declare that there is no conflict of interest to reveal.

\section{References}

Agizzio AP, Da Cunha M, Carvalho AO, Oliveira MA, Ribeiro $\mathrm{SFF}$, Gomes VM. The antifungal properties of a $2 \mathrm{~S}$ albuminhomologous protein from passion fruit seeds involve plasma membrane permeabilization and ultra structural alterations in yeast cells. Plant Sci. 2006; 17: 515-22.

Balandrin MF, Klocke JA, Wutule ES, Bollinger WH. Natural plant chemicals: Sources of industrial and medicinal materials. Science 1985; 228: 1154-60.

Batra V, Rajagopalan TR. Alkaloidal constituents of Senecio scandens. Curr Sci. 1977; 46: 141.

Bohlmann F, Knoll KH, Zdero C, Mahanta PK, Greaz M, Suwita A, Ehlera A, Le Van N, Abraham WR, Natu AA. Terpen-derivate aus Senecio-arten. Phytochemistry 1977; 16: 965-85.

Brito SM, Coutinho HD, Talvani A, Coronel C, Barbosa AG, Vega C, Figueredo FG, Tintino SR, Lima LF, Boligon AA, Athayde ML, Menezes IR. Analysis of bioactivities and chemical composition of Ziziphus joazeiro Mart. using HPLCDAD. Food Chem. 2015; 186: 185-91.

Cabral V, Luo X, Junqueira E, Costa SS, Mulhovo S, Duarte A, Couto I, Viveiros M, Ferreira MJ. Enhancing activity of antibiotics against Staphylococcus aureus: Zanthoxylum capense constituents and derivatives. Phytomedicine. 2015; 15; 22: 469-76. 
Djouossi MG, Tamokou JD, Ngnokam D, Kuiate JR, Tapondjou LA, Harakat D, Voutquenne-Nazabadioko L. Antimicrobial and anti-oxidant flavonoids from the leaves of Oncoba spinosa Forssk. (Salicaceae). BMC Complement Altern Med. 2015; 28; 15: 134

Harrison JW, Svec TA. The beginning of the end of the antibiotic era? Part II. Proposed solutions to antibiotic abuse. Quintessence Int. 1998; 29: 223-29.

Jones FA. Herbs-useful plants. Their role in history and today. Eur J Gastroenterology Hepatol. 1996; 8: 1227-31.

Mota AS, Martins MR, Arantes S, Lopes VR, Bettencourt E, Pombal S, Gomes AC, Silva LA. Antimicrobial activity and chemical composition of the essential oils of Portuguese Foeniculum vulgare fruits. Nat Prod Commun. 2015; 10: 67376.

Rao GG. Risk factors for the spread of antibiotic-resistant bacteria. Drugs. 1998; 55: 323-30.

Satish S, Raveesha KA, Janardhana GR. Antibacterial activity of plant extracts of phytopathogenic Xanthomonas campestris pathovars. Lett Appl Microbiol. 1999; 28: 145-147.

Tian XY, Wang YH, Yang QY, Liu X, Fang WS, Yu SS. Jacaranone glycosides from Senecio scandens. J Asian Nat Prod Res. 2006; 8: 125-32.

Wang D, Huang L, Chen S. Senecio scandens Buch.-Ham.: A review on its ethnopharmacology, phytochemistry, pharmacology, and toxicity. J Ethnopharmacol. 2013; 149: 1-23.

Wang XF, Tu DJ. Studies on the chemical constituents of Senecio scandens Buch,-Ham (author's transl). Acta Pharm Sin. 1980; 15: 503-05.

Weisser R, Asscher AW, Winpenny J. In vitro reversal of antibiotic resistance by ethylenediamine tetraacetic acid. Nature 1996; 219: 1365-66.

Yu J, Lei J, Yu H, Cai X, Zou G. Chemical composition and anti -microbial activity of the essential oil of Scutellaria barbata. Phytochemistry 2004; 65: 881-84.

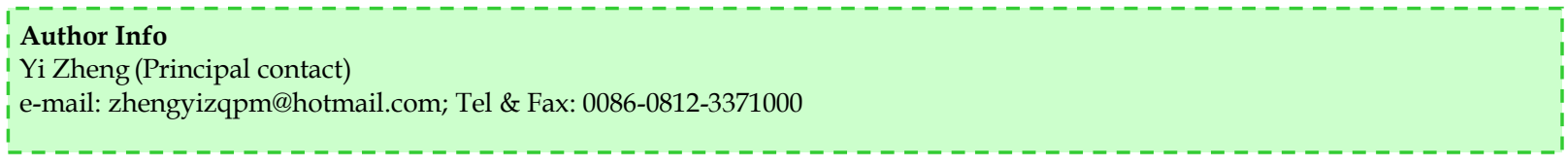




\section{Your feedback about this paper}

1. Number of times you have read this paper 0

2. Quality of paper Click

3. Your comments

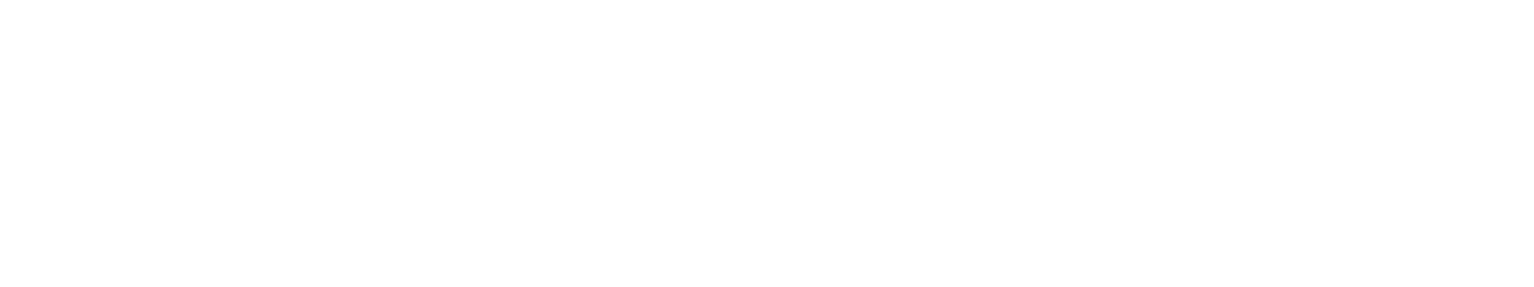

